\title{
Empowering rural women through entrepreneurship training programmes
}

\author{
SHIVANI RANA
}

Received: 07.01.2017; Revised: 13.04.2017; Accepted: 30.04.2017

AUTHOR FOR CORRESPONDENCE

\section{SHIVANI RANA}

Krishi Vigyan Kendra, FARIDKOT (PUNJAB) INDIA
ABSTRACT : Krishi Vigyan Kendra designs different kinds of training courses for the farmers/ farm women/rural girls. Courses are based on the information received through family and village survey. No specific qualification is required to be the participant of training programmes. After conducting training programmes, follow- up programmes are organised for converting the obtained skills of the trainees into practice. The vocational training programmes take into account all methods and means which will result in skill development in rural women and girls in the areas of their interest. A study was undertaken with the objective to assess the vocational training programmes on knowledge gained by the rural women and its role in their empowerment. The present study was conducted in district Faridkot of Punjab state which were selected purposively as the KVK was catering the needs of the farmers/farm women. A sample of 35 rural women trained by the KVK, Faridkot was selected purposively. Six different vocational training programmes were imparted by the KVK Home Science scientist. These were preservation of fruits and vegetables, different embroideries, value addition of flowers, value addition of wax, cutting and stitching, surf making and value added products from fruits and vegetables. Several lectures were delivered. Charts/posters were prepared and demonstrations were given of different steps included in each activity. A pre and post test performa developed for the trainings was filled upto assess the knowledge of the rural women participated in the training programmes. Vocational trainings played an important role in developing the skills among the rural youths and also benefiting the rural women for generation of income. Such training programmes can be replicated elsewhere and some more need based vocational training programmes may be incorporated so that the rural women and girls can earn their livelihood.

KEY WORDS: Vocational trainings, Livelihood, Empowerment

- HOW TO CITE THIS PAPER : Rana, Shivani (2017). Empowering rural women through entrepreneurship training programmes. Asian J. Home Sci., 12 (1) : 155-158, DOI: 10.15740/HAS/AJHS/12.1/155-158. 